Research Article

\title{
Field Monitoring and Numerical Analysis of the Reinforced Concrete Foundation of a Large-Scale Wind Turbine
}

\author{
Yanming Zhou, ${ }^{1}$ Xinxi Liu, ${ }^{1}$ Zongwei Deng $\mathbb{D}^{2},{ }^{2}$ and Qian-Feng Gao ${ }^{3}{ }^{3}$ \\ ${ }^{1}$ School of Civil Engineering, Changsha University of Science and Technology, Changsha 410114, China \\ ${ }^{2}$ College of Civil Engineering, Hunan City University, Yiyang 413000, China \\ ${ }^{3}$ School of Traffic and Transportation Engineering, Changsha University of Science and Technology, Changsha 410114, China
}

Correspondence should be addressed to Zongwei Deng; dengzongwei@hncu.edu.cn

Received 4 May 2021; Revised 21 June 2021; Accepted 25 June 2021; Published 5 July 2021

Academic Editor: Peng Zhang

Copyright (c) 2021 Yanming Zhou et al. This is an open access article distributed under the Creative Commons Attribution License, which permits unrestricted use, distribution, and reproduction in any medium, provided the original work is properly cited.

The objective of this study is to examine the performance of the shallow reinforced concrete foundation of a large-scale wind turbine under the influence of environmental loads. A $2 \mathrm{MW}$ horizontal-axis onshore wind turbine supported by a shallow concrete foundation was considered. The foundation stresses, foundation settlements, and static and dynamic contact pressures at various positions of the shallow foundation were monitored from the construction phase to the operation phase in the field. Numerical simulations were also performed to further analyze the behavior of the wind turbine foundation in different cases. The results demonstrate that the responses of the reinforced concrete foundation, i.e., foundation stresses, contact pressures, and foundation settlements, were variables closely related to the wind direction and wind speed. The distribution of foundation stresses suggested that a reasonable design of steel reinforcement cages around the foundation steel ring is important. The dynamic contact pressure of the foundation could reach $5 \mathrm{kPa}$, so the influence of dynamic wind loads on the foundation response could not be always neglected, particularly for the foundations seated on weak soils. The foundation settlement during the operation phase could be characterized by the logistic model, but its distribution was uneven due to the presence of eccentric upper weight and wind load. The findings would provide guidance for the foundation design of onshore wind turbines in hilly areas.

\section{Introduction}

As a clean, safe, and sustainable natural source, wind energy becomes increasingly important in power supply [1-3]. Plenty of new wind farms have been installed in mountainous and hilly regions in many countries as a strategy for narrowing the regional energy disparity $[4,5]$. For instance, from 2016 to 2020, China has built 42,000 MW wind turbines in its central eastern and southern regions $[6,7]$, where there are mainly hilly, plateau, and mountainous terrains. Wind turbines therein are usually supported by large-scale shallow foundations lied on the strongly weathered rock, karst, or residual soils. Unlike building structures, dynamic wind loads are the main forces for a wind turbine, which could produce considerable vibrations and increased stresses, strains, and deformations in the structure, foundation, and subsoil [8-10]. Therefore, the shallow foundation of a wind turbine in mountainous and hilly regions must show satisfactory performances in resisting large wind loads.

To date, various methods have been applied to analyze the responses of shallow foundations [11-13]. Al-Homoud and Al-Maaitah [14] carried out forced vertical vibration tests on shallow foundations resting on sand. The authors reported that the natural frequency increases while the vibration amplitude declines as the embedment depth, degree of saturation, and foundation base area increase. EI Sawwaf and Nazir [15] performed model tests on strip foundations supported on a loose sandy slope under both monotonic and cyclic loads. Their results indicated that the inclusion of soil reinforcement in the replaced sand not only significantly increases the stability of the sandy slope itself but also decreases much both the monotonic and cumulative cyclic settlements. Pasten et al. [16] developed a numerical method 
to analyze dynamic responses under repetitive vertical loads. It was found that the vertical settlement, horizontal displacement, foundation rotation, and stress redistribution within the soil mass change with increasing number of load cycles. Moreover, the displacement and rotation become more pronounced as the cyclic load amplitude increases. Chen et al. [17] conducted dimensionless parametric analyses to evaluate the dynamic responses of soil-foundation systems subjected to harmonic horizontal forces and rocking moments. Panique Lazcano et al. [18] proposed a pore-water pressure generation equation and evaluated the influence of pore pressure in the calculation of bearing capacity of shallow foundation on cohesive soil. The formulation is able to calculate the maximum cyclic load that a cohesive soil can resist before failure. Fattah et al. [19] examined the distribution of contact pressures under a circular shallow foundation subjected to vertical and rocking vibrations. It was found that the shallow foundation tends to have escalated stress distribution in the direction of rocking vibration to reach a peak at the center followed by a gentle drop.

Nevertheless, only a few related works have been reported in the field of wind turbines $[3,4]$. The work of Harte et al. [20] and Taddei et al. [21] stated that the soil-structure interaction plays an important role in the performance of wind turbine shallow foundations. Madaschi et al. [22] examined the dynamic behavior of the shallow foundation of a small full-scale wind turbine. It was noted that the vibration of the wind turbine tower induces a sort of forced, damped harmonic excitation in the foundation. More recently, Gao et al. [9] and Deng et al. [23] conducted numerical simulations and physical model tests on a $2 \mathrm{MW}$ wind turbine subjected to random wind loads. The authors demonstrated that the surrounding environment of the wind turbine foundation is affected by dynamic wind loads, and the dynamic amplification factors strongly depend on the wind speed and spatial position. However, the previous work did not concern the behavior of wind turbine foundation itself in the construction phase. Using numerical methods, Pham et al. [24] analyzed the responses of the shallow foundation of an onshore wind turbine resting on natural or improved ground. They stated that the soil settlement and the foundation rotation decrease when the area improvement ratio increases; meanwhile, the presence of the overturning moment on the raft increases the total and differential soil settlements. Wang and Ishihara [25] developed a dynamic Winkler model for the dynamic response analysis of shallow foundation supported wind turbines. It was found that without considering the foundation uplift, the moment on the wind turbine tower is slightly overestimated, while that on the shallow foundation is significantly underestimated for the large soil stiffness. He et al. [10] conducted structural health monitoring of a $1.5 \mathrm{MW}$ onshore wind turbine foundation with embedded ring. The authors reported that the long-term monitoring of the local concrete deformation is necessary to ensure the safety of the foundation, but their work mainly focused on the performance of embedded rings.

The purpose of the current study is to investigate the performance of wind turbine foundations under environmental loads. A common $2 \mathrm{MW}$ horizontal-axis wind turbine supported by a shallow concrete foundation was considered. The foundation stresses, foundation settlements, static contact pressures, and dynamic contact pressures at various positions of the shallow foundation of this type of wind turbine were collected from a wind farm in China. Numerical simulations were also conducted to further examine the performance of the wind turbine foundation. The monitored data and calculated results were analyzed and compared. The findings obtained from this study would provide guidance for the design of wind turbine foundations in hilly and mountainous areas.

\section{Engineering Background}

The Qiaoshi wind farm $\left(25^{\circ} 29^{\prime} 06.4^{\prime \prime} \mathrm{N}, 112^{\circ} 40^{\prime} 16.7^{\prime \prime} \mathrm{E}\right)$ is located in Guiyang County, Chenzhou City, China (Figure 1). This region is a subtropical monsoon climate, with abundant rainfall and distinctive seasons. Over the past 40 years, the average annual temperature is $17.2^{\circ} \mathrm{C}$, the average annual wind speed is $2.04 \mathrm{~m} / \mathrm{s}$, and the maximum average annual wind speed is $2.65 \mathrm{~m} / \mathrm{s}$. The prevailing wind direction is from the north-northeast (NNE) and south (S), among which the NNE direction has the largest frequency of about $15 \%$. The elevation of the Qiaoshi wind farm is $400-600 \mathrm{~m}$, and the landscape is characterized by low hills with mean slopes of $15^{\circ}-30^{\circ}$. The natural surface of the ground is covered by low shrubs. The ground is extensively covered with quaternary residual soils, and the bedrocks mainly include granite porphyry, limestone, sandstone, and dolomite. Dozens of $2 \mathrm{MW}$ horizontal-axis wind turbines (XEMC Windpower Company, China) have been installed on this wind farm. The specification of the wind turbine is shown in Table 1. All wind turbines were installed on hill tops or ridges and supported by circular spread foundations made of reinforced concrete. The external diameters and the embedment depths of the foundations were $18.4 \mathrm{~m}$ and $3.1 \mathrm{~m}$, respectively.

A representative wind turbine on the Qiaoshi wind farm was investigated. The wind turbine was supported by a circular spread concrete foundation that was situated on a hillside. The physical and mechanical properties of the subsoil and bedrock are shown in Table 2 .

\section{Study Methods}

3.1. Field Monitoring. The monitored items included the foundation stress, the foundation settlement, and the static and dynamic contact pressures between the foundation and the subsoil, which are important indicators to evaluate the performance of a shallow foundation.

The axial stresses of many steel bars in different positions and directions of the shallow foundation were monitored by stress gauges (see Figure 2). On the one hand, 32 stress gauges labeled SG-V1- $0^{\circ} \sim 335^{\circ}$, SG-V2- $0^{\circ} \sim 335^{\circ}$, SG-V3$0^{\circ} \sim 335^{\circ}$ and SG-V4- $0^{\circ} \sim 335^{\circ}$ were set to measure the axial stresses of the vertical steel bars in the foundation. On the other hand, another 32 stress gauges (i.e., SG-B1- $0^{\circ} \sim 335^{\circ}$, SG-B2- $0^{\circ} \sim 335^{\circ}$, SG-T1- $0^{\circ} \sim 335^{\circ}$, and SG-T2- $0^{\circ} \sim 335^{\circ}$ ) were 


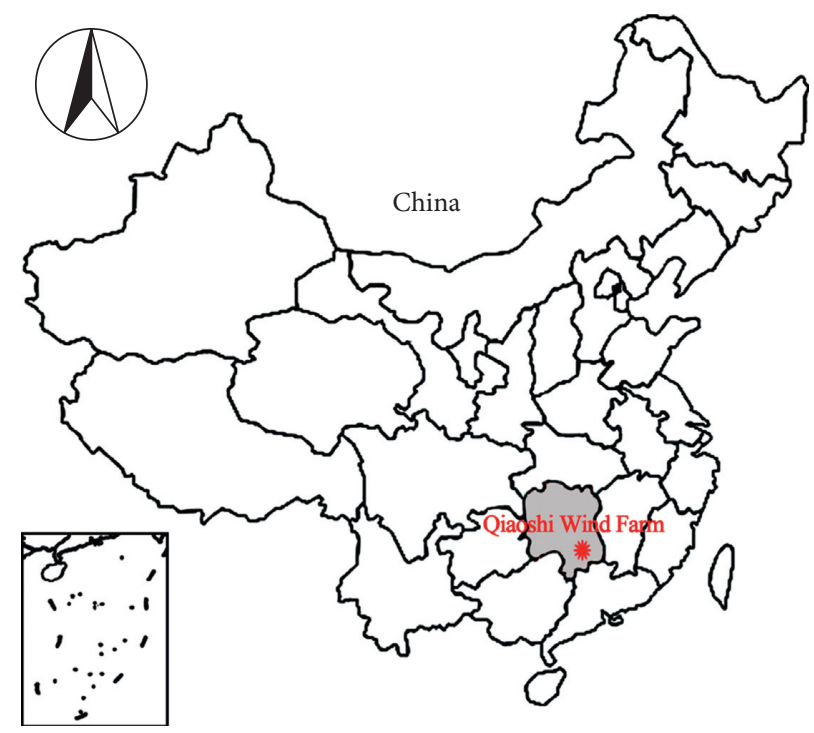

Figure 1: Geographical location of Qiaoshi wind farm $\left(25^{\circ} 29^{\prime} 06.4^{\prime \prime} \mathrm{N} 112^{\circ} 40^{\prime} 16.7^{\prime \prime} \mathrm{E}\right)$.

TABLE 1: Specification of the $2 \mathrm{MW}$ horizontal-axis wind turbine.

\begin{tabular}{lcccccc}
\hline $\begin{array}{l}\text { Rated output power } \\
(\mathrm{MW})\end{array}$ & $\begin{array}{c}\text { Rotor diameter } \\
(\mathrm{m})\end{array}$ & $\begin{array}{c}\text { Hub height } \\
(\mathrm{m})\end{array}$ & $\begin{array}{c}\text { Rated wind speed } \\
(\mathrm{m} / \mathrm{s})\end{array}$ & $\begin{array}{c}\text { Rated rotor speed } \\
(\mathrm{r} / \mathrm{min})\end{array}$ & $\begin{array}{c}\text { Nacelle and rotor } \\
\text { mass }(\mathrm{t})\end{array}$ & $\begin{array}{c}\text { Tower mass } \\
(\mathrm{t})\end{array}$ \\
\hline 2.0 & 93.4 & 80.0 & 11.0 & 12.3 & 128.5 & 155.0 \\
\hline
\end{tabular}

TABle 2: Physical and mechanical properties of the soil and rock.

\begin{tabular}{|c|c|c|c|c|c|c|c|}
\hline Soil/rock & $\begin{array}{l}\text { Thickness } \\
(\mathrm{m})\end{array}$ & $\begin{array}{l}\text { Natural density } \\
\left(\mathrm{g} / \mathrm{cm}^{3}\right)\end{array}$ & $\begin{array}{l}\text { Specific } \\
\text { gravity }\end{array}$ & $\begin{array}{c}\text { Internal friction } \\
\text { angle }\left({ }^{\circ}\right)\end{array}$ & $\begin{array}{c}\text { Cohesion } \\
(\mathrm{kPa})\end{array}$ & $\begin{array}{l}\text { Modulus } \\
(\mathrm{MPa})\end{array}$ & $\begin{array}{c}\text { Bearing } \\
\text { capacity }(\mathrm{kPa}) \\
\end{array}$ \\
\hline Residual soil & $3-6$ & $1.7-2.1$ & 2.70 & $15-20$ & $12-22$ & $5-8$ & $150-220$ \\
\hline $\begin{array}{l}\text { Strongly weathered } \\
\text { sandy shale }\end{array}$ & $4-12$ & $2.4-2.5$ & $2.6-2.7$ & - & - & 8000-10000 & $200-400$ \\
\hline $\begin{array}{l}\text { Moderately weathered } \\
\text { sandy shale }\end{array}$ & $>20$ & $2.5-2.6$ & $2.65-2.75$ & - & - & $11000-12000$ & $>500$ \\
\hline
\end{tabular}

Note: The data in the "modulus" column represent the compressive modulus for residual soil and the deformation modulus for rocks.

used to acquire the axial stresses of the radial steel bars near the foundation bottom and top surfaces in eight directions. The axis direction of each cylinder marking in Figure 2 represents the test direction of a stress gauge. Note that the $0^{\circ}$ direction represents the prevailing wind direction in this study. The stress gauges had a measurement range of $-200 \mathrm{MPa}-350 \mathrm{MPa}$, a sensitivity of $0.1 \mathrm{MPa}$, and a precision of $0.2 \%$ FS.

The geometric leveling method was used to observe the settlements of the wind turbine foundation. Four observation marks (i.e., SM- $0^{\circ} \sim 270^{\circ}$ ) were fixed on the foundation edge in different directions, as shown in Figure 3. The benchmark was positioned on the exposed bedrock near the foundation. During the observation, closed leveling lines were established from the benchmarks and passing each observation mark. The closing error of the leveling line must be less than $\pm 5 \sqrt{L}$ ( $L$ is the distance).
Static Earth pressure cells were employed to monitor the static contact pressures between the foundation and the subsoil [26]. The Earth pressure cells were circular with $118 \mathrm{~mm}$ in diameter and $30 \mathrm{~mm}$ in thickness. The Earth pressure cells had a measurement range of $0.6 \mathrm{MPa}, \mathrm{a}$ sensitivity of $0.1 \mathrm{kPa}$, and a precision of $0.1 \%$ FS. Their locations are illustrated in Figure 4. One Earth pressure cell (i.e., $\mathrm{PC} 0-0^{\circ}$ ) was installed in the center of the foundation bottom, eight Earth pressure cells (i.e., PC1 $-0^{\circ} \sim 315^{\circ}$ ) were placed in eight directions at a radius of $3 \mathrm{~m}$, and another eight Earth pressure cells (i.e., $\mathrm{PC} 2-0^{\circ} \sim 315^{\circ}$ ) were installed in eight directions at a radius of $6 \mathrm{~m}$. Static Earth pressure cells were also used to measure the static contact pressures between the lateral surface of the foundation and the backfill. Four Earth pressure cells (i.e., PC-S- $0^{\circ} \sim 270^{\circ}$ ) were fixed in four directions at a shallow depth, and another four Earth pressure cells (i.e., PC-D- $0^{\circ} \sim 270^{\circ}$ ) were installed in four 


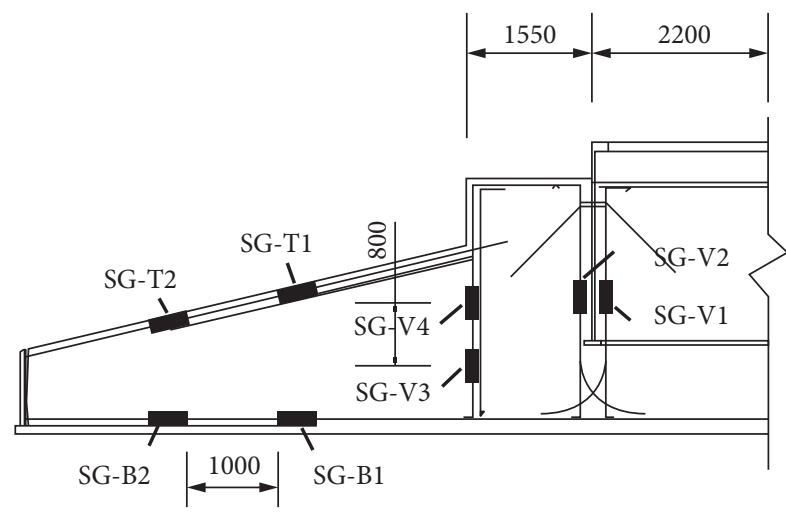

SG: Stress gauge

Unit: $\mathrm{mm}$

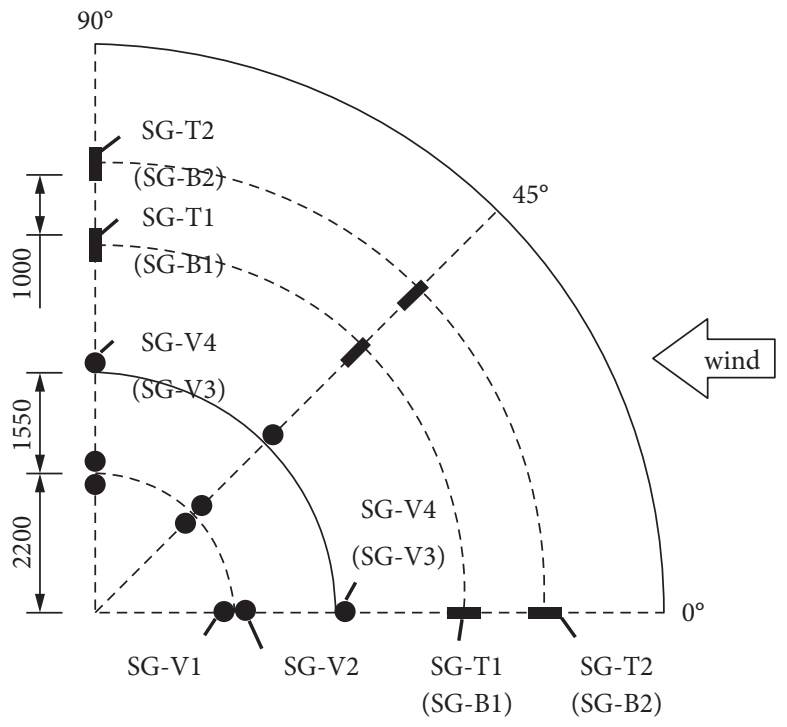

SG: Stress gauge

Unit: $\mathrm{mm}$

(a)

(b)

FIGURE 2: Layout drawing of stress gauges in the foundation.

SM: settlement observation mark

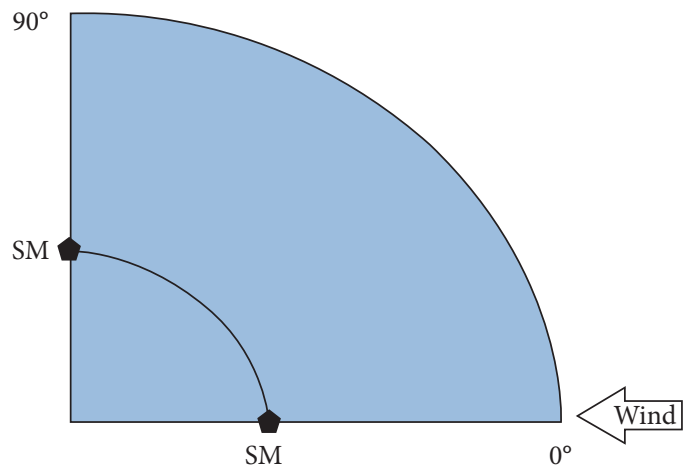

Top view

FiguRE 3: Layout drawing of settlement observation marks on the foundation.

PC: static earth pressure cell DPC: dynamic earth pressure cell
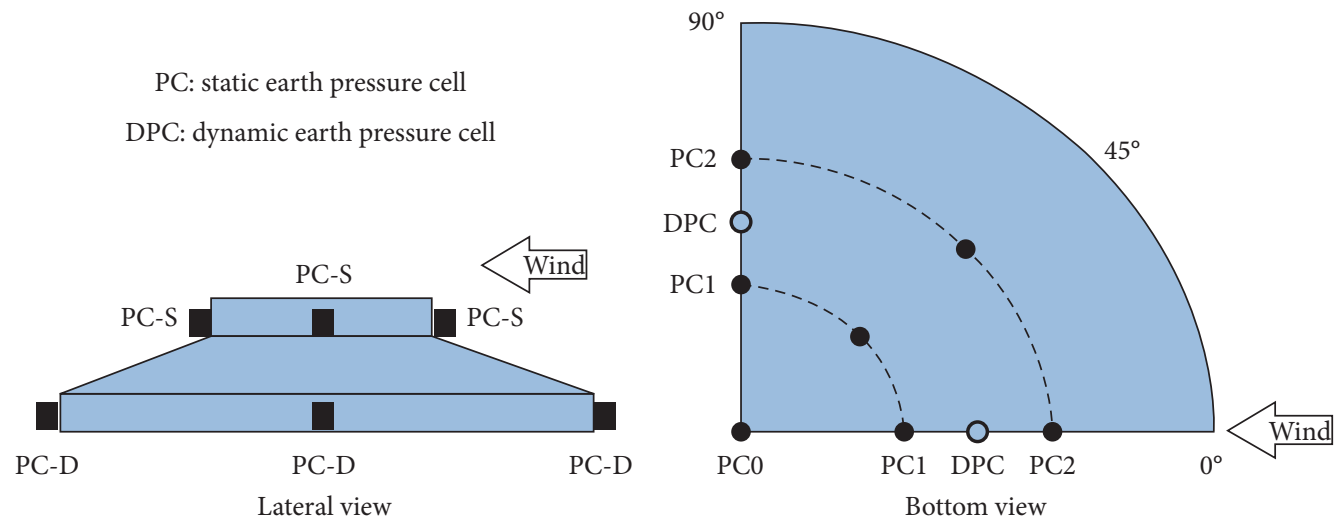

Figure 4: Layout drawing of Earth pressure cells on the bottom and lateral surface of the foundation. 
directions at a deeper position. In addition, the dynamic contact pressures of the wind turbine foundation were monitored using four dynamic Earth pressure cells (i.e., DPC- $0^{\circ} \sim 270^{\circ}$ ) with a range of $0.8 \mathrm{MPa}$ and a precision of $0.1 \mathrm{kPa}$.

The field monitoring started at the beginning of the construction phase of the foundation and lasted to the operation phase of the wind turbine. Some important time points of the construction and operation phases are listed in Table 3.

\section{Numerical Simulation}

A three-dimensional numerical model of the wind turbine foundation is created using the finite element software ABAQUS, as shown in Figure 5. The model basically consists of the foundation (the steel ring, the steel reinforcement cage, and concrete) and the subsoil (diameter $=80 \mathrm{~m}$, height $=30 \mathrm{~m}$ ). The dimension of the foundation model is the same as that of the foundation of the monitored wind turbine on the Qiaoshi wind farm. For simplicity, the subsoil is regarded to be a single layer of residual soils. This simplification will not greatly affect the numerical results since this study mainly focuses on the response of the foundation rather than the behavior of the subsoil. The concrete and steel are modeled as isotropic elastic materials, and the subsoil is modeled using the Mohr-Coulomb model. The material properties used in the simulation are given in Table 4 . The used soil properties are failing into the ranges of measured data shown in Table 2. The properties of the steel and concrete are determined referring to relevant Chinese specifications $[27,28]$. The steel reinforcement cage is simulated by beam elements (B31), while the remaining parts (i.e., concrete, subsoil, and steel ring) are simulated by solid elements (C3D10). [29] The element size is determined after convergence analysis considering the calculation accuracy and computation cost. The whole finite element model contains 63895 elements and 56941 nodes in total.

The steel reinforcement cage is linked to the concrete using the embedded technique [30]. Coulomb's friction law with a friction coefficient of 0.35 is applied to simulate the tangential behavior between the foundation and the subsoil $[4,9]$. The contact in the normal direction at the interface between the foundation and the subsoil is considered to be a hard contact. The mesh tie constraint provided in ABAQUS is adopted to connect the concrete to the steel ring. The bottom boundary of the model is fully fixed in both the vertical and horizontal directions, and the lateral boundary of the finite element model is fixed in the horizontal direction. Two cases (i.e., \#1 and \#2) with wind speeds of $12 \mathrm{~m} /$ $\mathrm{s}$ and $14 \mathrm{~m} / \mathrm{s}$ at the hub height are considered in simulations to compare with the monitored results. The loads transmitted from the superstructure to the foundation top are simplified into a horizontal load, a vertical load, and a moment rotating around a horizontal axis [3]. The loads shown in Table 5 are calculated using the GH Bladed software, which is a commercial software widely used in wind turbine design and analysis.
TABLE 3: Important time points of the construction and operation phases.

\begin{tabular}{lcc}
\hline Day & Phase & Description \\
\hline 0 & & Construct the foundation \\
35 & & Backfill the foundation pit \\
68 & Construction & Install the tower \\
74 & & Install the nacelle and rotor \\
86 & Complete the installation \\
\hline 103 & & Start the operation \\
117 & Operation & Operation case $1 \#$ (hub wind speed $=12 \mathrm{~m} / \mathrm{s}$ ) \\
200 & & Operation case 2\# (hub wind speed $=14 \mathrm{~m} / \mathrm{s}$ ) \\
$\ldots$ & & Continue the operation \\
\hline
\end{tabular}

\section{Results and Discussion}

5.1. Foundation Stress. Figure 6 illustrates the simulated axial stress contours of the entire steel reinforcement cage of the foundation in difference cases. It is observed that in both cases (i.e., \#1 and \#2) the axial stresses of the steel reinforcement cage were in the range of $-10 \mathrm{MPa}-5 \mathrm{MPa}$, which were far less than the strengths of the steel. Moreover, the part on the downwind side likely undergone compressive stress while that on the upwind side generally withstood tensile stress. Compared with the circumferential steel bars, the radial steel bars and vertical steel bars suffer higher stresses. Both the maximum compressive stress and tensile stress appeared in the vertical steel bars near the foundation steel ring. It suggests that a reasonable design of the steel reinforcement cage around the foundation steel ring is critical for the safety of the shallow foundation of a wind turbine [10].

Figures 7 and 8 compare the axial stresses of steel bars in the foundation obtained by field monitoring and numerical simulations. It is noted that some of the vertical steel bars (e.g., SG-V2- $90^{\circ}, 135^{\circ}, 180^{\circ}, 225^{\circ}$ in Case \#1) were in tension while the others (e.g., SG-V2-270 $315^{\circ}, 0^{\circ}, 45^{\circ}$ in Case \#1) were in compression. Furthermore, the axial stresses of the vertical steel bars were obviously affected by the wind speed. Generally, the larger the wind speed was, the larger the horizontal wind load and moment applied to the wind turbine were, and thus the larger the tensile stresses or compressive stresses of the vertical steel bars were. The vertical steel bars at SG-V3 and SG-V4 mainly suffered compressive stresses. The radial steel bars near the foundation top surface (i.e., at SG-T1 and SG-T2) were mainly in compression while the radial steel bars on the foundation bottom (i.e., at SG-B1 and SG-B2) were mainly in tension. Overall, both the simulated and monitored results showed similar variations and distributions although the values were not exactly the same. This is reasonable because some simplifications or assumptions are made to the materials and loads in numerical simulations. Hence, the numerical model is considered to be capable of characterizing the behavior of the wind turbine foundation for engineering purposes.

5.2. Static Contact Pressure. Figure 9 presents the time histories of the monitored static contact pressures on the foundation bottom. It is observed that the static contact 


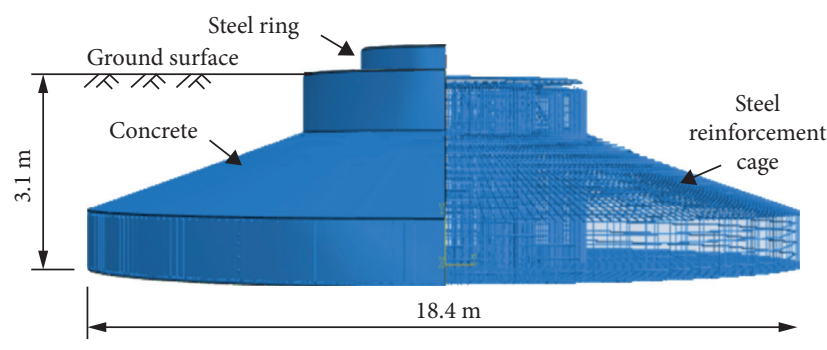

(a)

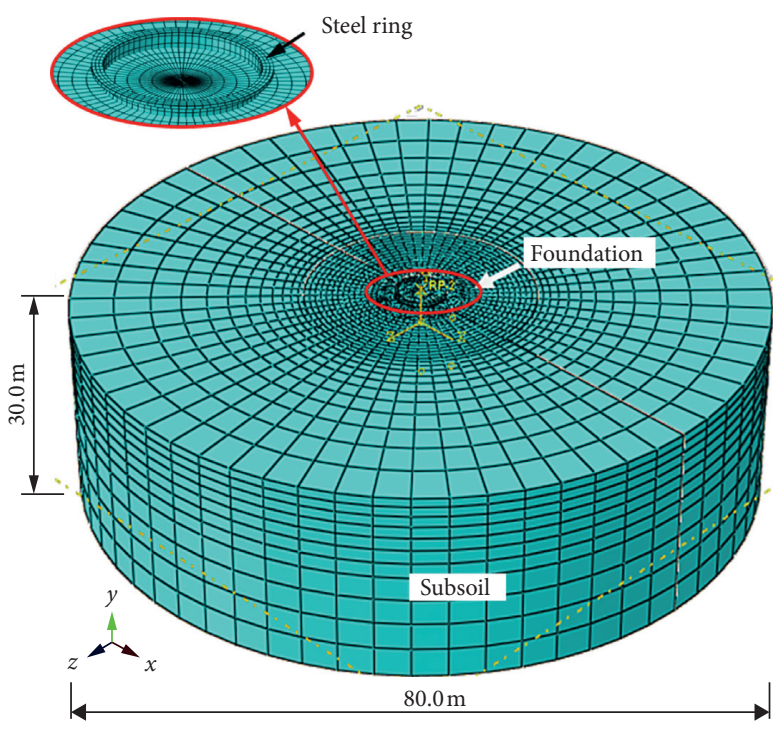

(b)

FIgURE 5: Numerical model of the wind turbine foundation and subsoil: (a) foundation model; (b) element generation.

TABLE 4: Material properties used in numerical simulations.

\begin{tabular}{|c|c|c|c|c|c|c|}
\hline Material & $\begin{array}{l}\text { Mass density } \rho \\
\left(\mathrm{kg} / \mathrm{m}^{3}\right)\end{array}$ & $\begin{array}{c}\text { Elastic modulus } E \\
(\mathrm{MPa})\end{array}$ & $\begin{array}{l}\text { Poisson's } \\
\text { ratio } \mu\end{array}$ & $\begin{array}{c}\text { Internal friction } \\
\text { angle } \psi\left(\left(^{\circ}\right)\right.\end{array}$ & $\begin{array}{c}\text { Cohesion } c \\
(\mathrm{kPa})\end{array}$ & $\begin{array}{c}\text { Bearing capacity } \\
(\mathrm{kPa})\end{array}$ \\
\hline Subsoil & 2000 & 20 & 0.4 & 18 & 20 & 200 \\
\hline Steel ring & 7850 & 206000 & 0.3 & - & - & - \\
\hline $\begin{array}{l}\text { Steel reinforcement } \\
\text { cage }\end{array}$ & 7850 & 200000 & 0.3 & - & - & - \\
\hline Concrete & 2500 & 31500 & 0.2 & - & - & - \\
\hline
\end{tabular}

TABLe 5: Loading cases.

\begin{tabular}{lcccc}
\hline Case & Hub wind speed $v(\mathrm{~m} / \mathrm{s})$ & Vertical load $F_{\mathrm{v}}(\mathrm{kN})$ & Horizontal load $F_{\mathrm{h}}(\mathrm{kN})$ & Horizontal moment $M_{\mathrm{h}}(\mathrm{kN} \cdot \mathrm{m})$ \\
\hline$\# 1$ & 12.0 & 2649.5 & 184.0 & 11115.0 \\
$\# 2$ & 14.0 & 2653.2 & 243.0 & 15492.0 \\
\hline
\end{tabular}

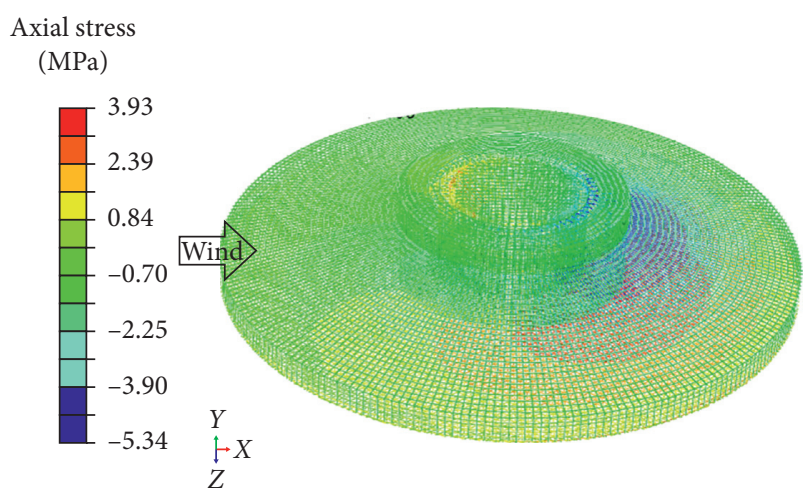

(a)

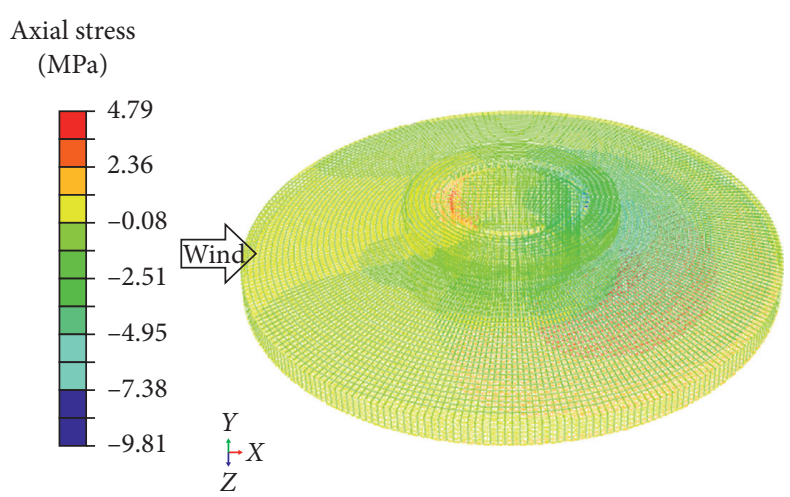

(b)

Figure 6: Simulated axial stress contours of the steel reinforcement cage: (a) in Case \#1; (b) in Case \#2. 


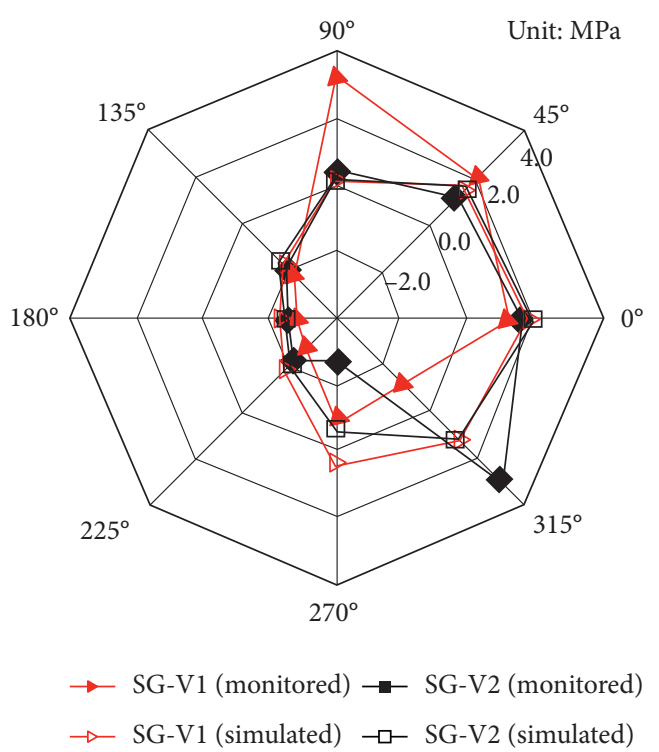

(a)

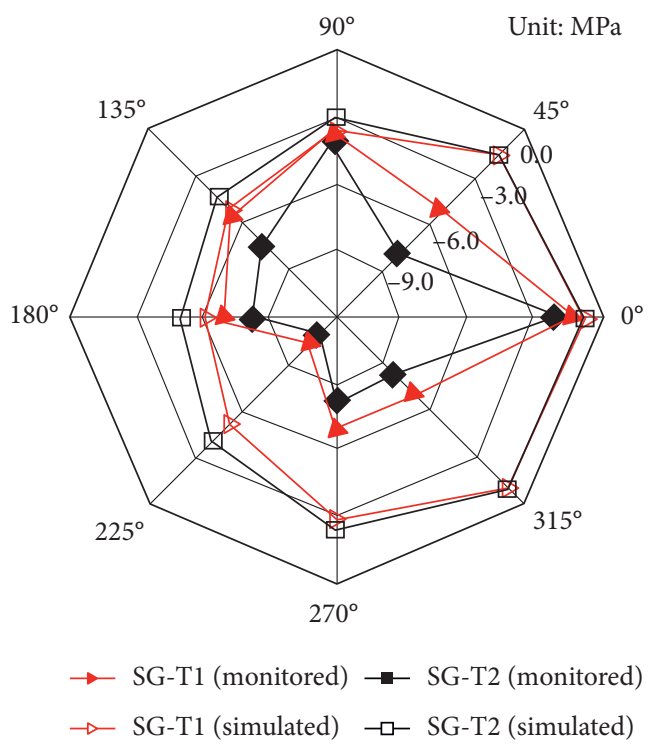

(c)

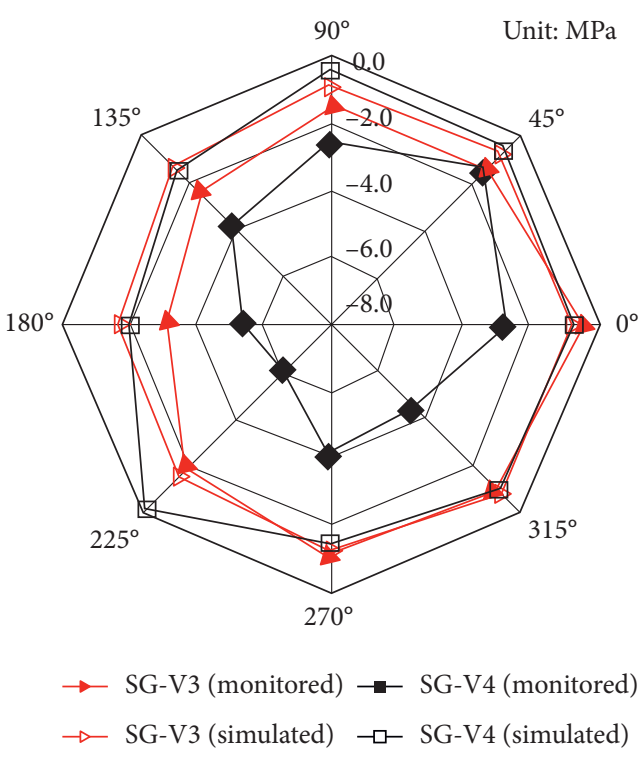

(b)

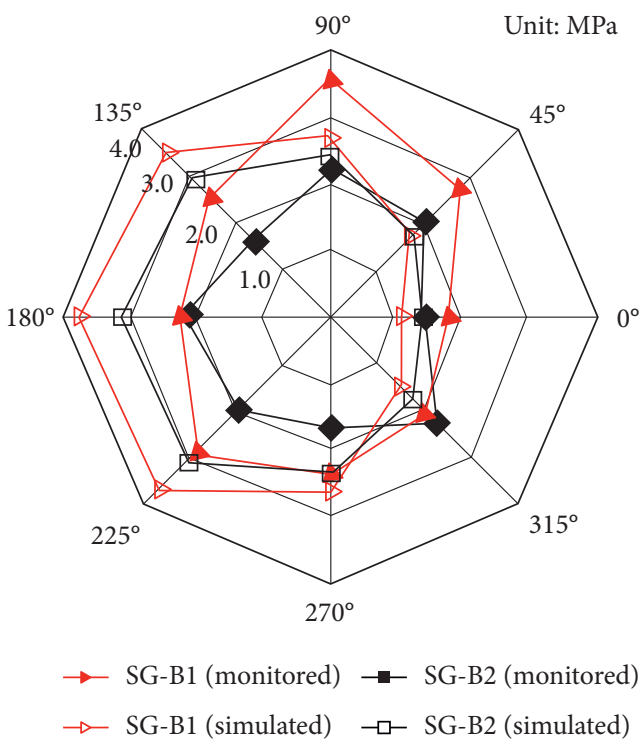

(d)

Figure 7: Axial stresses of steel bars in the foundation in Case \#1: (a) at SG-V1 and SG-V2; (b) at SG-V3 and SG-V4; (c) at SG-T1 and SG-T2; (d) at SG-B1 and SG-B2.

pressures at various monitoring points considerably went up during the foundation construction and backfilling process (i.e., $t=0-35 \mathrm{~d}$ ). As the superstructure (i.e., tower, nacelle, and rotor) was gradually installed on the foundation (i.e., $t=68-86 \mathrm{~d}$ ), the distribution of static contact pressures gradually slightly varied from homogeneous to uneven due to the eccentricity of the weight of wind turbine superstructure. During the operation of the wind turbine (i.e., $t>103 \mathrm{~d}$ ), large wind loads were applied to the superstructure of the wind turbine; this led to an obvious variation of the static contact pressure. In this process, the direction of the monitoring point where the static contact pressure was the maximum changed with the change in wind direction. Furthermore, one can note that the static contact pressures at PC2 were generally smaller than those at PC1. The static contact pressures on the upwind side were smaller than those monitored on the downwind side, which is in line with the axial stresses of steel bars on the foundation bottom.

Figure 10 illustrates the simulated contours of static contact pressures on the foundation bottom in two different cases (i.e., \#1 and \#2). It is observed that the static contact pressure was not homogeneously distributed but exhibited large values on the downwind side and relatively small values on the upwind side. This finding is broadly in agreement with the monitored results and those reported in the literature [9]. The abnormal contact pressures at individual points in Case \#1 appear due to stress concentrations when the eccentricity of the foundation is relatively small. 


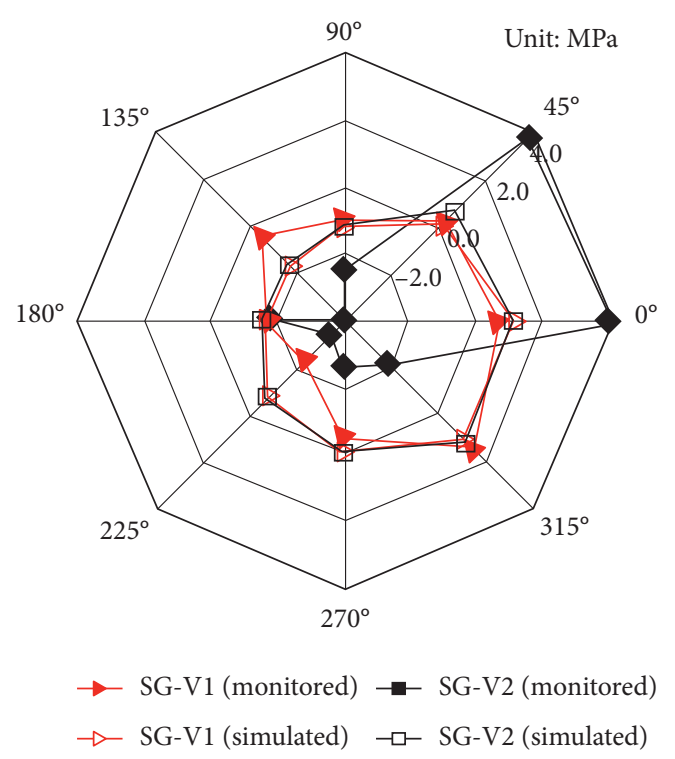

(a)

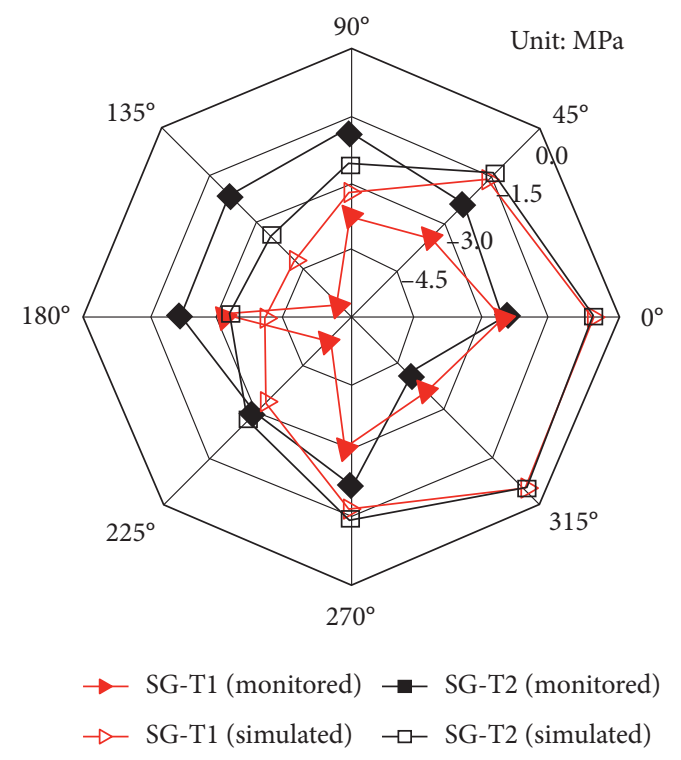

(c)

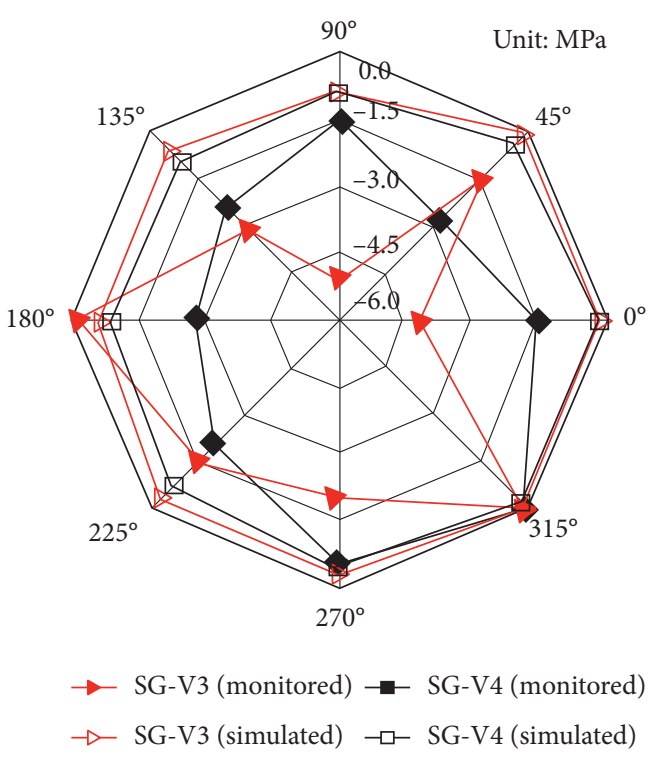

(b)

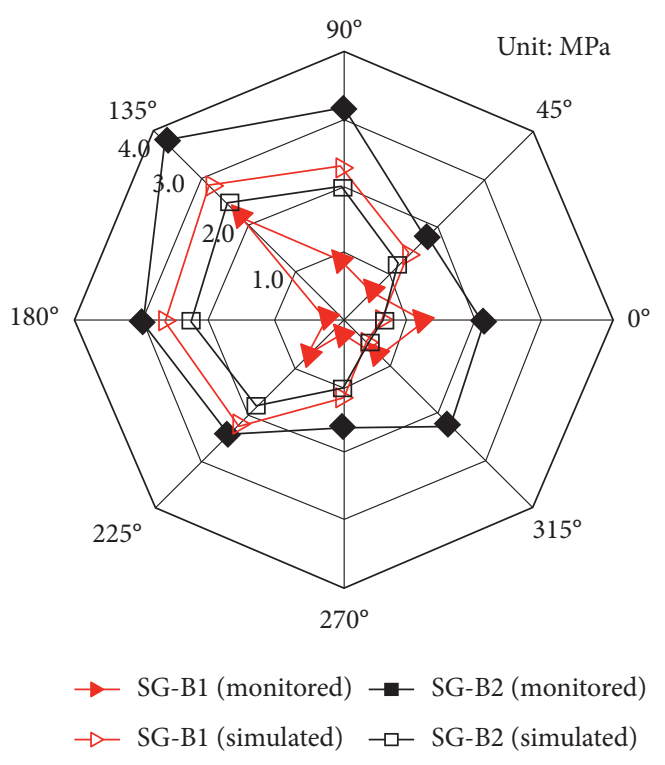

(d)

FIGURE 8: Axial stresses of steel bars in the foundation in Case \#2: (a) at SG-V1 and SG-V2; (b) at SG-V3 and SG-V4; (c) at SG-T1 and SG-T2; (d) at SG-B1 and SG-B2.

Figure 11 compares the simulated static contact pressures with those monitored in the field. Obviously, the simulated data and the monitored values were not precisely consistent. But, as expected, the simulated and monitored static contact pressures showed similar distributions. Additionally, one can note that the distribution of static contact pressures on the foundation bottom was affected by the wind speed. For example, the static contact pressures monitored on $t=117 \mathrm{~d}$ with a hub wind speed of $12 \mathrm{~m} / \mathrm{s}$ were quite different from those monitored on $t=200 \mathrm{~d}$ with a hub wind speed of about $14 \mathrm{~m} / \mathrm{s}$.

Figure 12 presents the time histories of the monitored static contact pressures on the lateral side of the foundation. As expected, the static lateral contact pressures at a smaller depth (i.e., PC-S) were smaller than those at a larger depth (i.e., PC-D). Generally, the static lateral contact pressures of the foundation showed a similar variation trend as the static contact pressures on the foundation bottom during the process of foundation construction and backfilling (see Figure 9). In this process, the static lateral contact pressures considerably increased from zero up to around $13 \mathrm{kPa}$ at PC$\mathrm{S}$ and $34 \mathrm{kPa}$ at $\mathrm{PC}-\mathrm{D}$, respectively. Afterward, the static lateral contact pressures exhibited great fluctuations during the installation of the superstructure of the wind turbine and relatively small fluctuations during the operation phase. As a whole, the static contact pressures on the lateral side of the foundation are several times smaller than those on the bottom. 


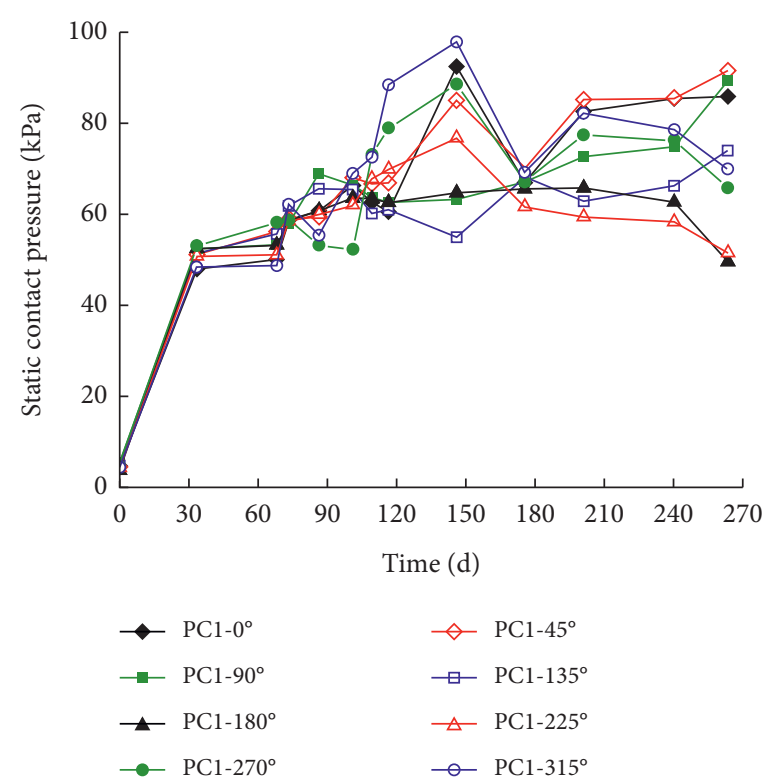

(a)

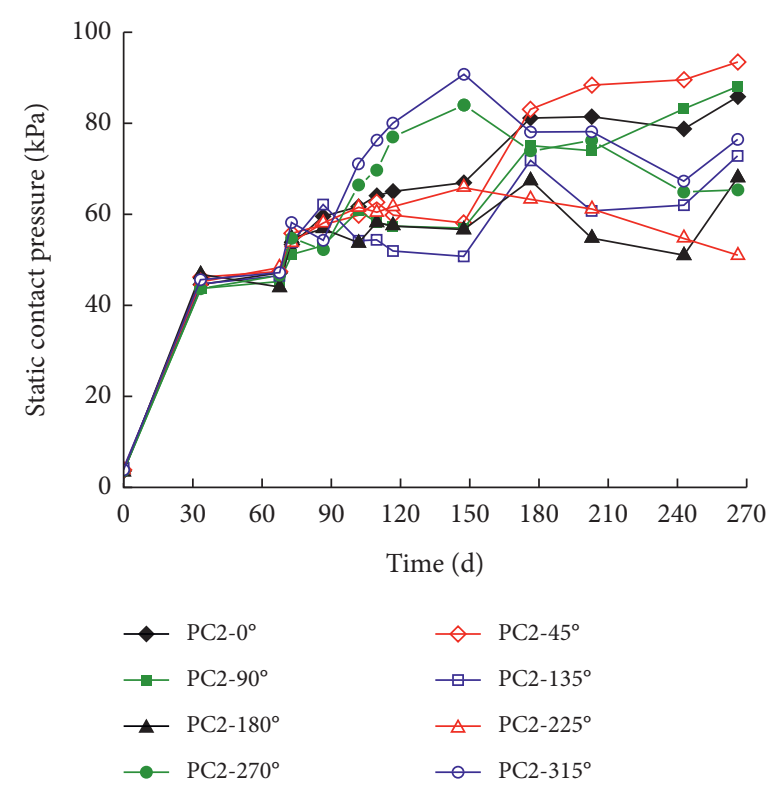

(b)

FIgURE 9: Time histories of monitored static contact pressures on the foundation bottom: (a) at PC1; (b) at PC2.

Contact pressure $(\mathrm{kPa})$
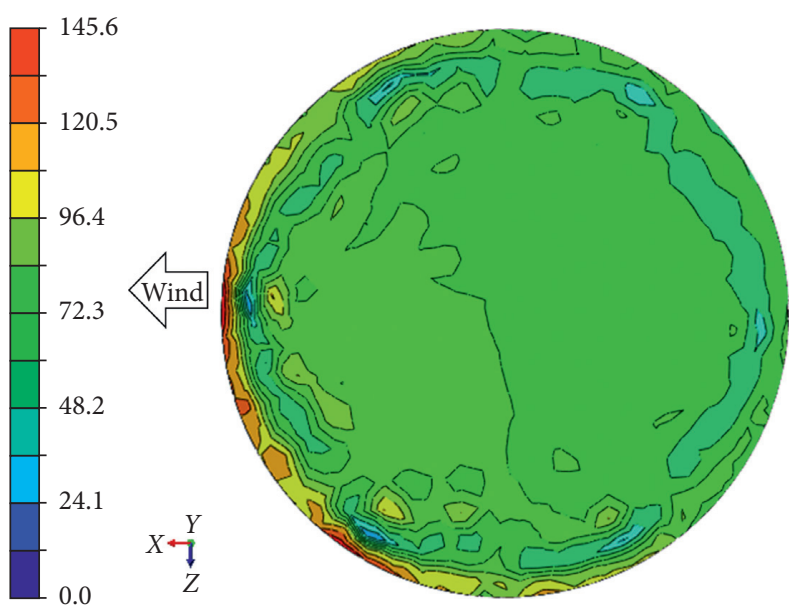

(a)
Contact pressure $(\mathrm{kPa})$
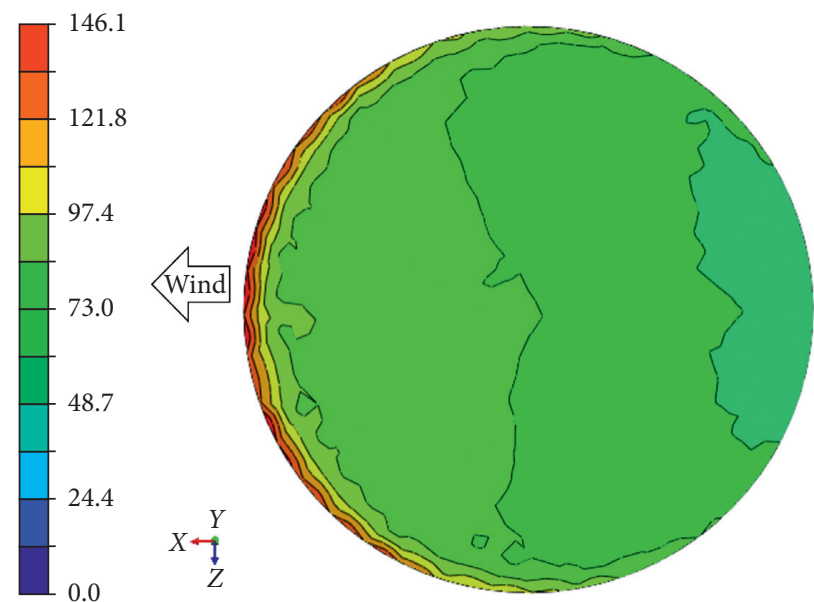

(b)

FIgURE 10: Simulated contours of static contact pressures on the foundation bottom: (a) in Case \#1; (b) in Case \#2.

\section{Foundation Settlement}

Figure 13 shows the time histories of the foundation settlements from the backfilling phase to the operation phase. It is noted that the foundation settlements slightly increased when the foundation pit was backfilled (i.e., $t=35-68 \mathrm{~d}$ ). During the installation of the superstructure of the wind turbine (i.e., $t=68-86 \mathrm{~d}$ ), the foundation settlement showed a significant increase in a step-like manner. This is because the tower sections, nacelle, and wind rotor were installed successively. One can also note a slight wave of the curve in this process; this is likely due to the movement of wheel cranes and transport vehicles. Moreover, because of the eccentricity of the upper weights and the existence of wind loads, the foundation settlements at different positions were different. The foundation settlements were then stabilized during the period between $t=86 \mathrm{~d}$ and $t=103 \mathrm{~d}$. As the operation of the wind turbine was started (i.e., $t>103 \mathrm{~d}$ ), the foundation settlements increased with a decreasing rate. Three months later, the foundation settlements reached the equilibrium. After the equilibrium, the maximum foundation settlement was about $15.0 \mathrm{~mm}$ at $\mathrm{SM}-180^{\circ}$, and the minimum foundation settlement was $8.6 \mathrm{~mm}$ at $\mathrm{SM}-0^{\circ}$. The differential settlement was $(15.0-8.6) \mathrm{mm} / 7.5 \mathrm{~m}=0.85 \mathrm{~mm} /$ 


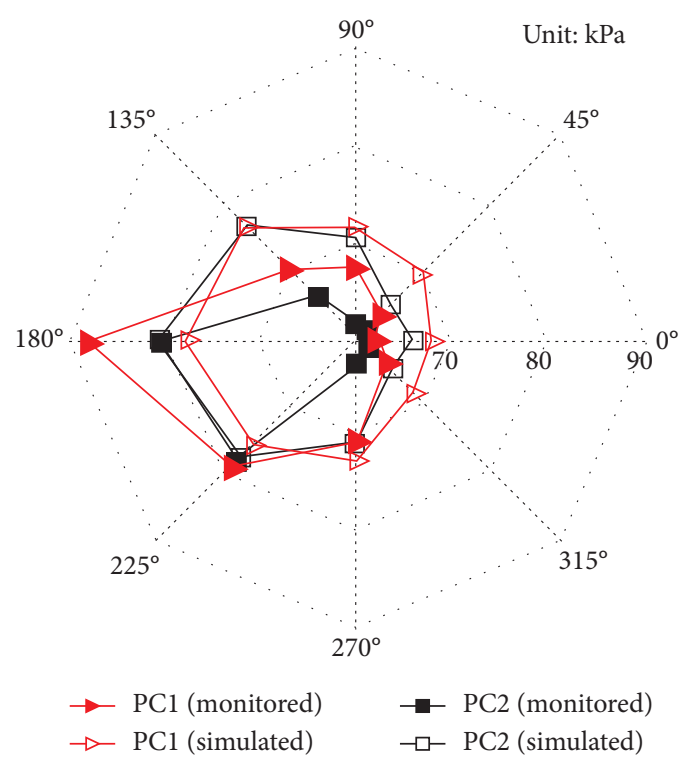

(a)

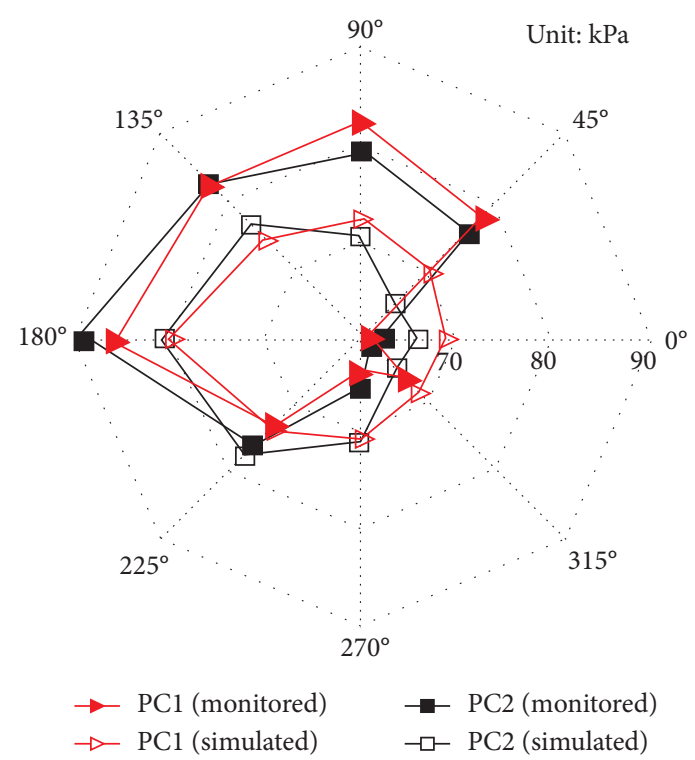

(b)

Figure 11: Comparison between monitored and simulated static contact pressures: (a) in Case \#1; (b) in Case \#2.

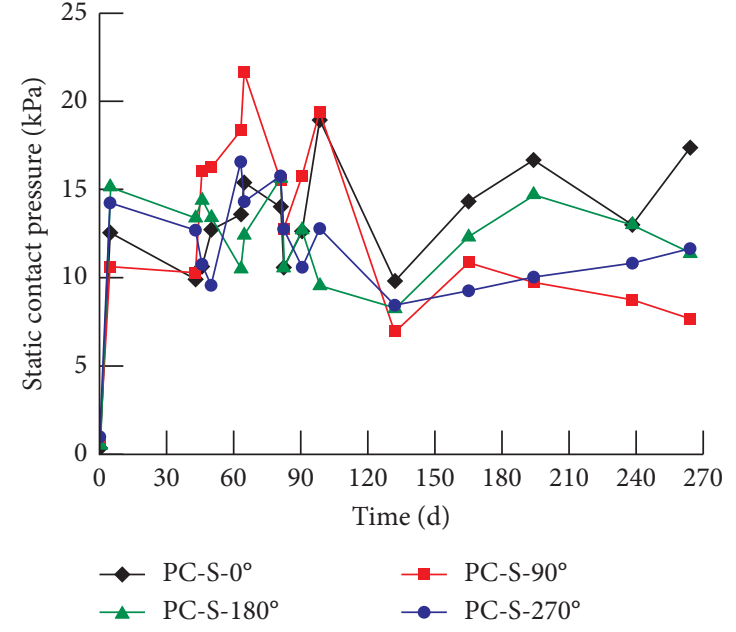

(a)

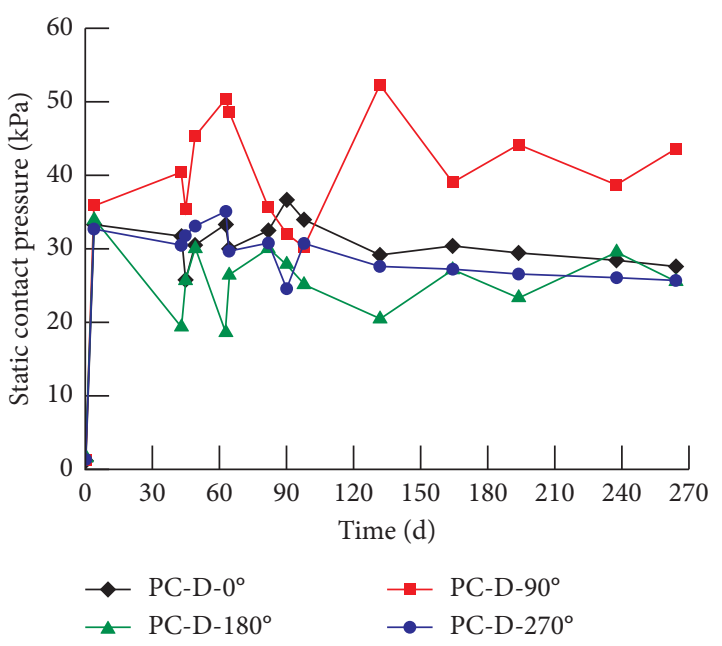

(b)

FIgURE 12: Time histories of static lateral contact pressures of the foundation: (a) at PC-S; (b) at PC-D.

$\mathrm{m}$, which is in the range of allowable value [31]. This indicates that the wind turbine foundation was stable.

The variation of foundation settlements during the operation can be described by the logistic model, which has the following form:

$$
s=\frac{K}{1+c e^{-a t}},
$$

where $s$ is the settlement of the wind turbine foundation; $t$ is the time; $a$ is the instant settlement rate; $K$ is the final settlement; $c$ is a constant.

The fitting parameters of two example curves are summarized in Table 6. It shows that the logistic model can well characterize the settlement evolution of the wind turbine foundation.

Figure 14 depicts the simulated contour of the foundation settlement. One can note that the foundation settlement showed an uneven distribution. The simulated settlements of the foundation baseplate varied from $20.0 \mathrm{~mm}$ to $25.6 \mathrm{~mm}$ in Case \#1 and from $19.0 \mathrm{~mm}$ to $26.9 \mathrm{~mm}$ in Case \#2. The simulated foundation settlements were nearly twice the monitored results, but they had the same order of magnitude. The numerical work of Gao et al. [9] showed that the maximum settlement at a hub wind speed of $11 \mathrm{~m} / \mathrm{s}$ is about $3.5 \mathrm{~mm}$, occurring near the downwind edge of the foundation. Obviously, the previous results are close to those of the current study. 


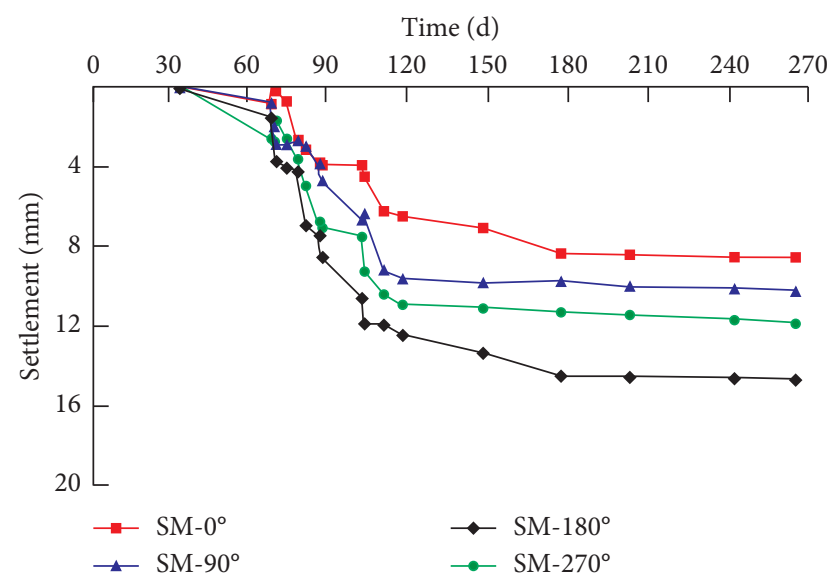

Figure 13: Time histories of the settlements of wind turbine foundation.

Table 6: Parameters of the logistic model.

\begin{tabular}{lccrr}
\hline Monitoring point & $K$ & $a$ & $c$ & $R^{2}$ \\
\hline $\mathrm{SM}-0^{\circ}$ & 8.58 & 0.0386 & 4.09 & 0.985 \\
$\mathrm{SM}-180^{\circ}$ & 15.09 & 0.0296 & 3.96 & 0.943 \\
\hline
\end{tabular}

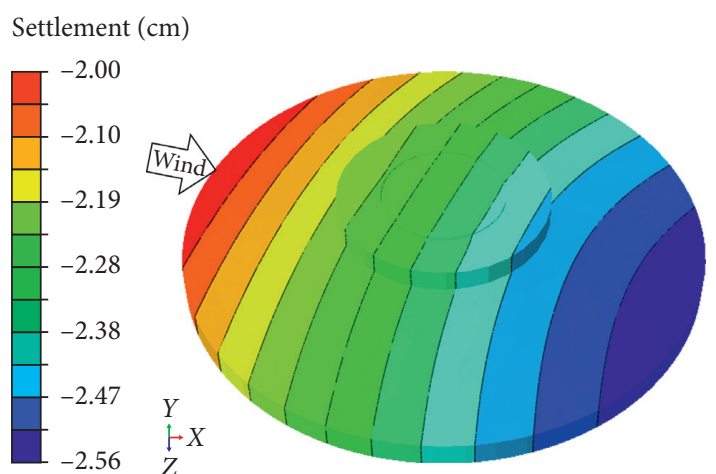

(a)

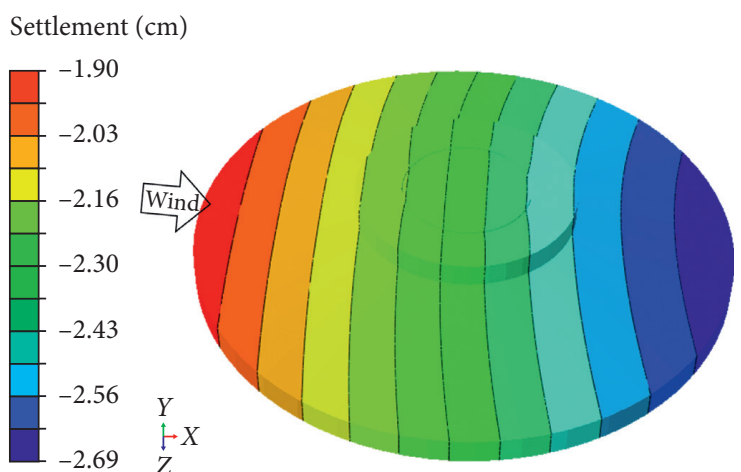

(b)

FIGURE 14: Simulated settlement contours of the shallow foundation: (a) in Case \#1; (b) in Case \#2.

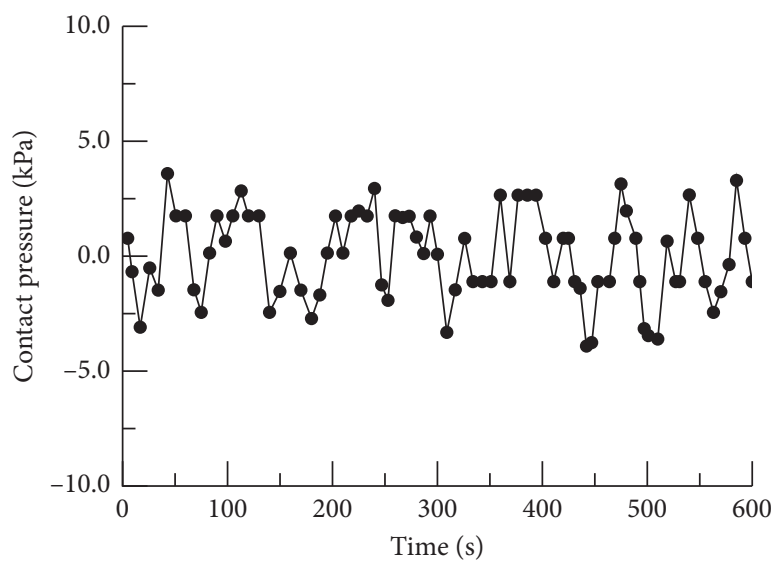

(a)

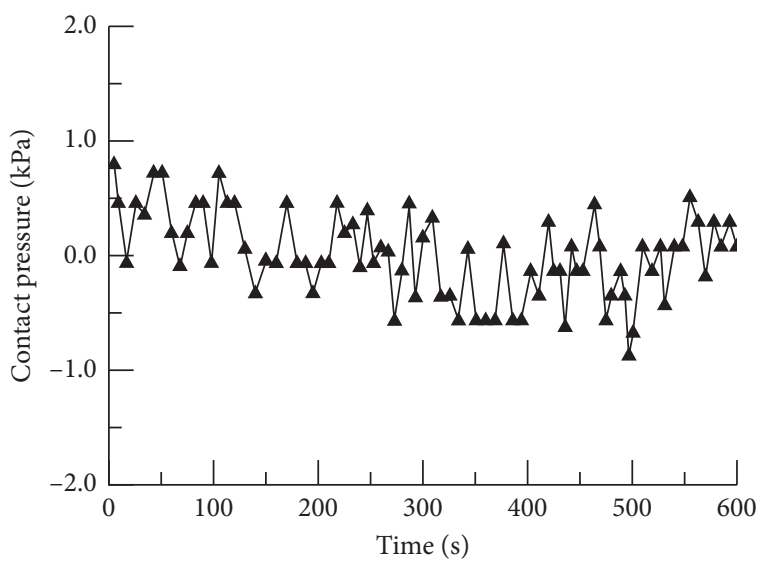

(b)

Figure 15: Continued. 


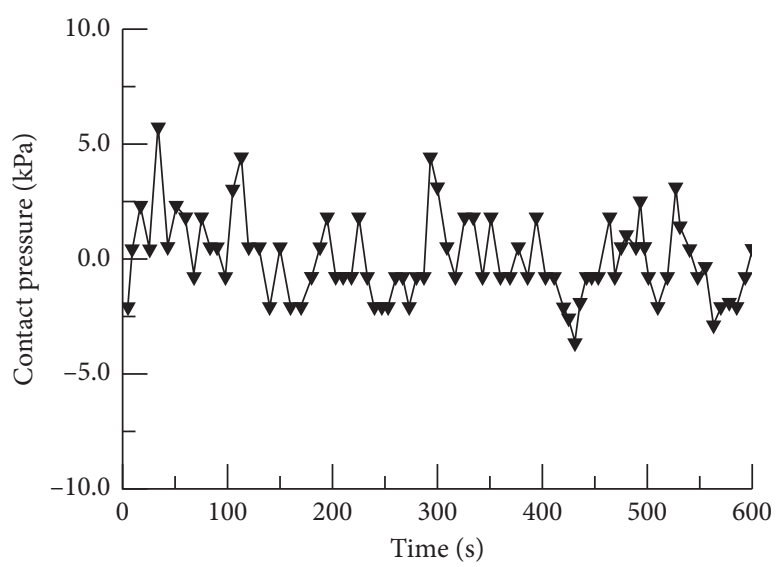

(c)

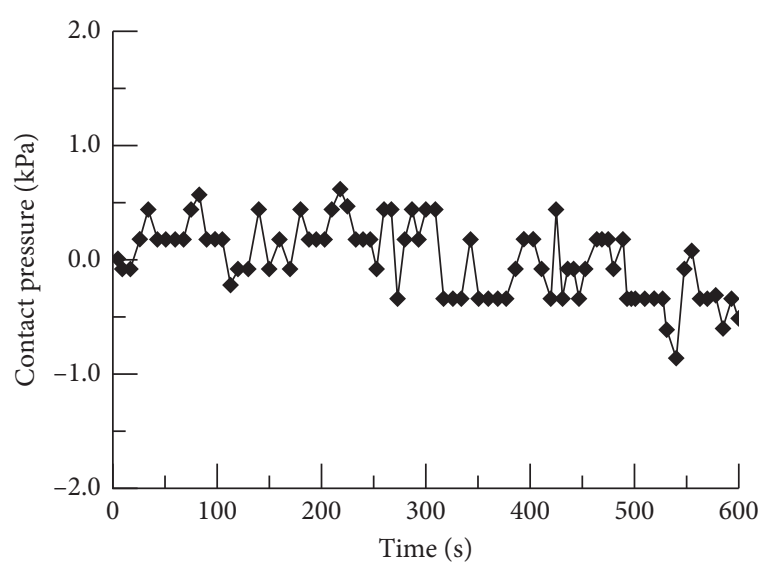

(d)

FIgURE 15: Time histories of monitored dynamic contact pressures on the foundation bottom: (a) at DPC- $0^{\circ}$; (b) at DPC-90 $0^{\circ}$ (c) at DPC$180^{\circ}$; (d) at DPC- $270^{\circ}$.

6.1. Dynamic Contact Pressure. Figure 15 presents the time histories of the dynamic (i.e., fluctuating) contact pressures in Case \#1. It is noted that the maximum dynamic contact pressure was $3.59 \mathrm{kPa}$ at $\mathrm{DPC}-0^{\circ}$. Since $\mathrm{DPC}-0^{\circ}$ was located between $\mathrm{PC} 1-0^{\circ}$ and $\mathrm{PC} 2-0^{\circ}$ (Figure 11 ), the static contact pressure at $\mathrm{DPC}-0^{\circ}$ is assumed to be the average value of the static contact pressures at $\mathrm{PC} 1-0^{\circ}$ and $\mathrm{PC} 2-0^{\circ}$. The estimated static contact pressure at DPC- $0^{\circ}$ was about $61.75 \mathrm{kPa}$, so the dynamic amplification factor at $\mathrm{DPC}-0^{\circ}$ was $3.59 /$ $61.75=5.8 \%$. Since the maximum dynamic contact pressure at $\mathrm{DPC}-180^{\circ}$ was $5.73 \mathrm{kPa}$ and the static contact pressure at DPC- $180^{\circ}$ was about $84.75 \mathrm{kPa}$, the dynamic amplification factor at DPC- $180^{\circ}$ was $5.73 / 84.75=6.8 \%$. Similarly, it is derived that maximum dynamic contact pressure was $0.79 \mathrm{kPa}$ and the dynamic amplification factor was $1.2 \%$ at DPC- $90^{\circ}$; the maximum dynamic contact pressure was $0.62 \mathrm{kPa}$ and the dynamic amplification factor was $1.0 \%$ at $\mathrm{DPC}-270^{\circ}$. These findings were roughly in agreement with those reported by Deng et al. [23], indicating that the wind load had a dynamic effect on the contact pressures of the wind turbine foundation.

\section{Conclusions}

This paper presented a case study of the reinforced concrete foundation of a large-scale wind turbine on the Qiaoshi wind farm in China. The foundation stresses, foundation settlements, static contact pressures, and dynamic contact pressures of the foundation at various positions were monitored and simulated. The following conclusions can be drawn:

(1) Radial steel bars in the foundation baseplate mainly underwent tensile stress while those near the top surface of the foundation mainly suffered from compressive stress. The stresses of the vertical steel bars were either compressive or tensile depending on the position. However, the stresses of all steel bars were far less than the tensile or compressive strength of the steel.
(2) The contact pressures on the bottom of the reinforced concrete foundation were variables that are highly dependent on the wind direction and wind speed. The dynamic contact pressure of the foundation could reach $5 \mathrm{kPa}$, indicating that the influence of dynamic wind loads on the performance of the reinforced concrete foundation should not be always neglected, particularly for the foundations seated on weak soils.

(3) The settlement of the wind turbine foundation was uneven due to the presence of eccentric upper weight and wind load. The monitored settlement values were usually in the range of $0-20 \mathrm{~mm}$ from the foundation backfilling phase to the operation phase. The evolution of foundation settlement during the operation phase could be characterized by the logistic model.

(4) A reasonable design of the steel reinforcement cage around the foundation steel ring is critical for the safety of the reinforced concrete foundation of wind turbines. Meanwhile, the wind-induced dynamic effect also needs to be taken into consideration in the design of wind turbine foundations although the effect may be not obvious in regular cases.

\section{Data Availability}

Because the data in the paper are still a project of the $\mathrm{Na}$ tional Natural Science Foundation of China, the data need to be used in the follow-up study of the project. So, all the figures and tables data used to support the findings of this study were supplied by the corresponding author under license and so cannot be made freely available. Requests for access to these data should be made to Zongwei Deng, Hunan City University, No. 518, Yingbin East Road, 413000, YiYang, Hunan, China (tel:086-13973760738; e-mail: dengzongwei@hncu.edu.cn). 


\section{Conflicts of Interest}

The authors declare that they have no conflicts of interest.

\section{Acknowledgments}

This work was supported by the Postgraduate Research and Innovation Project of Hunan Province (CX20190657), the National Natural Science Foundation of China (51674041 and 51474103), the Natural Science Foundation of Hunan Province, China (2020JJ4156), and the Changsha Municipal Natural Science Foundation (kq2014110).

\section{References}

[1] J. R. F. Diógenes, J. Claro, J. C. Rodrigues, and M. V. Loureiro, "Barriers to onshore wind energy implementation: a systematic review," Energy Research \& Social Science, vol. 60, Article ID 101337, 2020.

[2] C. H. Chiang, K. T. Hsu, C. P. Yu, C. C. Cheng, and J. Z. Pan, "Remote measurements and vibration analysis of existing wind turbines," Journal of Testing and Evaluation, vol. 47, no. 3, pp. 2193-2206, 2019.

[3] G. Xing, C. Liu, S. Li, and W. Xuan, "HM bearing capacity of cone-shaped foundation for onshore wind turbine under monotonic horizontal loading," Advances in Materials Science and Engineering, vol. 2019, Article ID 3409561, 14 pages, 2019.

[4] S. Li, Y. Zhang, and D. Li, "Capacity of cone-shaped hollow flexible reinforced concrete foundation (CHFRF) in sand under horizontal loading," Advances in Materials Science and Engineering, vol. 2020, Article ID 6346590, 14 pages, 2020.

[5] U. E. Hansen, I. Nygaard, M. Morris, and G. Robbins, "The effects of local content requirements in auction schemes for renewable energy in developing countries: a literature review," Renewable and Sustainable Energy Reviews, vol. 127, Article ID 109843, 2020.

[6] X. C. Fan and W. Q. Wang, "Spatial patterns and influencing factors of China' s wind turbine manufacturing industry: a review," Renewable and Sustainable Energy Reviews, vol. 54, pp. 482-496, 2016.

[7] L. Li, X. Ren, Y. Yang, P. Zhang, and X. Chen, "Analysis and recommendations for onshore wind power policies in China," Renewable and Sustainable Energy Reviews, vol. 82, pp. 156167, 2018.

[8] M. Lee, M. Yoo, K. Bae, Y. Kim, B. Nam, and H. Youn, "Centrifuge tests on the lateral behavior of offshore monopile in saturated dense sand under cyclic loading," Journal of Testing and Evaluation, vol. 47, no. 3, pp. 1809-1828, 2019.

[9] Q. F. Gao, H. Dong, Z. W. Deng, and Y. Y. Ma, "Wind-induced dynamic amplification effects on the shallow foundation of a horizontal-axis wind turbine," Computers and Geotechnics, vol. 88, pp. 9-17, 2017.

[10] M. He, X. Bai, R. Ma, and D. Huang, "Structural monitoring of an onshore wind turbine foundation using strain sensors," Structure and Infrastructure Engineering, vol. 15, no. 3, pp. 1-20, 2019.

[11] M. Shariati, S. M. Azar, M. A. Arjomand, H. S. Tehrani, M. Daei, and M. Safa, "Comparison of dynamic behavior of shallow foundations based on pile and geosynthetic materials in fine-grained clayey soils," Geomechanics and Engineering, vol. 19, no. 6, pp. 473-484, 2019.

[12] A. Kumar and S. Kumari, "Numerical modeling of shallow foundation on liquefiable soil under sinusoidal loading,"
Geotechnical \& Geological Engineering, vol. 37, no. 2, pp. 517-532, 2019.

[13] J. Qin, X. Zeng, F. H. Neff, and H. Ming, "Influence of fabric anisotropy on seismic response of circular foundation," Soil Dynamics and Earthquake Engineering, vol. 124, pp. 151-161, 2019.

[14] A. S. Al-Homoud and O. N. Al-Maaitah, "An experimental investigation of vertical vibration of model footings on sand," Soil Dynamics and Earthquake Engineering, vol. 15, no. 7, pp. 431-445, 1996.

[15] M. A. El Sawwaf and A. K. Nazir, "Cyclic settlement behavior of strip footings resting on reinforced layered sand slope," Journal of Advanced Research, vol. 3, no. 4, pp. 315-324, 2012.

[16] C. Pasten, H. Shin, and J. C. Santamarina, "Long-term foundation response to repetitive loading," Journal of Geotechnical and Geoenvironmental Engineering, vol. 140, no. 4, 2014.

[17] S.-S. Chen, K.-H. Liao, and J. Y. Shi, “A dimensionless parametric study for forced vibrations of foundation-soil systems," Computers and Geotechnics, vol. 76, pp. 184-193, 2016.

[18] D. R. Panique Lazcano, R. Galindo Aires, and H. Patiño Nieto, "Bearing capacity of shallow foundation under cyclic load on cohesive soil," Computers and Geotechnics, vol. 123, Article ID 103556, 2020.

[19] M. Y. Fattah, N. M. Salim, and K. K. Alwan, "Contact pressure distribution under circular shallow foundation subjected to vertical and rocking vibration modes," Journal of Building Engineering, vol. 26, Article ID 100908, 2019.

[20] M. Harte, B. Basu, and S. R. K. Nielsen, "Dynamic analysis of wind turbines including soil-structure interaction," Engineering Structures, vol. 45, pp. 509-518, 2012.

[21] F. Taddei, C. Butenweg, and S. Klinkel, "Parametric investigation of the soil-structure interaction effects on the dynamic behaviour of a shallow foundation supported wind turbine considering a layered soil," Wind Energy, vol. 18, no. 3, pp. 399-417, 2015.

[22] A. Madaschi, A. Gajo, M. Molinari, and D. Zonta, "Characterization of the dynamic behavior of shallow foundations with full-scale dynamic tests," Journal of Geotechnical and Geoenvironmental Engineering, vol. 142, no. 7, Article ID 04016026, 2016.

[23] Z.-W. Deng, Q.-F. Gao, H. Dong, and L.-X. Li, "Dynamic responses of the shallow foundation of an onshore wind turbine," International Journal of Physical Modelling in Geotechnics, vol. 19, no. 5, pp. 247-260, 2019.

[24] H. V. Pham, D. Dias, T. Miranda, N. Cristelo, and N. Araújo, "3D numerical modeling of foundation solutions for wind turbines," International Journal of Geomechanics, vol. 18, no. 12, 12 pages, Article ID 04018164, 2018.

[25] L. Wang and T. Ishihara, "A study of the effects of foundation uplift on the seismic loading of wind turbine tower and shallow foundation using a new dynamic Winkler model," Engineering Structures, vol. 219, Article ID 110745, 2020.

[26] J. Xiao, Y. Wang, D. Zhang, X. Zhang, and J. Guo, "Testing of contact stress at ballast bed-soil subgrade interface under cyclic loading using the thin-film pressure sensor," Journal of Testing and Evaluation, vol. 48. , 2020 In press.

[27] G. B. 50017, Standard for Design of Steel Structures, China Architecture\& Building Press, Beijing, China, 2017, in Chinese.

[28] G. B. 50010, Code for Design of Concrete Structures, China Architecture\& Building Press, Beijing, China, 2014, in Chinese. 
[29] A. A. El Ezz and K. Galal, "Compression behavior of confined concrete masonry boundary elements," Engineering Structures, vol. 132, pp. 562-575, 2017.

[30] W. Zhao, C. Du, L. Sun, and X. Chen, "Field measurements and numerical studies of the behaviour of anchored sheet pile walls constructed with excavating and backfilling procedures," Engineering Geology, vol. 259, Article ID 105165, 2019.

[31] E. Ntambakwa, H. Yu, C. Guzman, and M. Rogers, "Geotechnical design considerations for onshore wind turbine shallow foundations," Geotechnical and Structural Engineering Congress, vol. 2016, pp. 1153-1165, 2016. 